Research Article

\title{
Combined effect of retinoic acid and vascular endothelial growth factor on compensatory lung growth following unilateral pneumonectomy in rats
}

\author{
Saravanan $\mathbf{R}^{1 *}$, Rajaram $\mathbf{S}^{2}$
}

\begin{abstract}
${ }^{1}$ Department of Pharmacology, Vinayaka Missions University, Salem, Tamilnadu, India

${ }^{2}$ Department of Pharmacology, Vinayaka Missions Kirupananda Variyar Medical College and Hospital, Salem, Tamilnadu, India
\end{abstract}

Received: 06 April 2016

Accepted: 07 May 2016

\section{*Correspondence to: \\ Dr. Saravanan R, \\ Email: drsarvan.ssss \\ @ gmail.com}

Copyright: () the author(s), publisher and licensee Medip Academy. This is an openaccess article distributed under the terms of the Creative Commons Attribution NonCommercial License, which permits unrestricted noncommercial use, distribution, and reproduction in any medium, provided the original work is properly cited.

\begin{abstract}
Background: The most common complication of complete or partial pneumonectomy is insufficient oxygenation due to loss of respiratory unit leading to reduced quality of life. Retinoic acid and vascular endothelial growth factors are two important signaling molecules essential during normal lung development and together they could enhance the compensatory lung growth and function following pneumonectomy.

Methods: Unilateral pneumonectomy of left lung was performed in male wistar albino rats. Retinoic acid (RA) $(0.5 \mathrm{mg} / \mathrm{kg})$, vascular endothelial growth factor (VEGF) $5 \mu \mathrm{g} /$ day and vehicle were administered intraperitoneally for 10 days. Lung weight, lung volume, arterial blood gases (ABG), protein and DNA estimations were performed on the contralateral lung.

Results: Rats treated with RA alone and combination of RA and VEGF increased the weight and volume of the compensatory lung as compared to control. Protein and DNA concentrations were also increased in the contralateral lung in rats treated with RA alone and RA with VEGF as compared to control. In arterial blood gas analysis, rats treated with combination of RA and VEGF shows an increase in partial pressure of oxygen and oxygen saturation as compared to control, whereas rats treated with RA alone did not significantly improve the oxygen saturation.

Conclusions: Combination of VEGF with RA had accelerated compensatory lung growth in pneumonectomized rats probably by increasing type II pneumocyte proliferation and new blood vessels formation in the lung. There is significant increase in arterial blood gases compared to retinoic acid group possibly by the formation of new blood vessels by VEGF which is essential for improving oxygenation of blood and to improve quality of life.
\end{abstract}

Keywords: RA, VEGF, Pneumonectomy, Compensatory growth, ABG

\section{INTRODUCTION}

Lung volume reduction surgery (LVRS) is one of the palliative treatments performed in patients with advanced chronic obstructive pulmonary disease, severe emphysema and early stages of carcinomas. The most common complications that occur after complete or partial pneumonectomy is insufficient oxygenation to the body. The patient is usually asymptomatic at rest and the symptoms of insufficient oxygenation occur only at physical exercise and reduce the quality of life. Several reports and trials demonstrated an appreciable mortality without substantial improvement in lung function. ${ }^{1}$ The regenerative capacity of adult mammalian lung tissue can be utilized to improve the functional capacity of the lung in pneumonectomy and in disease conditions, where the lung function is impaired. Lung volume reduction surgery (LVRS) has been very effectively used as management in patients with severe emphysema. ${ }^{2}$ After complete or partial pneumonectomy, alveolar epithelial cells initiate proliferation of the remaining lobes by means of proliferation of type II pneumocytes, which is the putative resident progenitor cells. ${ }^{3}$ During lung injury and recovery, these type II cells increase in abundance. ${ }^{2}$ This 
proliferation takes place over and above the over inflation of the existing airspace and mere increase in lung weight and volume.

Retinoic acid (RA), a product of vitamin A metabolism is essential for the normal growth and development of lung and retinoic acid plays an important role in controlling fetal lung development. ${ }^{4}$ Exogenous RA administration in rats enhances indexes of alveolar septal formation during postnatal development. ${ }^{5}$ In cell culture studies, retinoic acid stimulates type II pneumocyte proliferation. ${ }^{6}$ Rats fed with vitamin A deficient diet had abnormal tracheal morphology and pulmonary morphology, but this abnormality is reversible once vitamin A was returned to their diet. ${ }^{7,8}$ Retinoic acid regulates a wide variety of genes and gene products in the lung. ${ }^{9,10}$ It also regulates embryonic morphogenesis. ${ }^{11}$ RA not only affects lung growth, it also affects the development of trachea and broncho-pulmonary structures. ${ }^{12}$

Angiogenesis is an important process in both physiological and pathological states. Angiogenesis plays a major role in wound healing as well as in tumor growth. Tumors secrete a variety of angiogenic factors to sprout new blood vessels to supply adequate nutrients. Antiangiogenic agents like thalidomide and fumagillin attenuate vascular growth and reduce alveolarization in developing rat lung. ${ }^{13}$

Vascular endothelial growth factor (VEGF) is a proangiogenic factor synthesized endogenously and plays role in normal vascular development in many organs. Type II pneumocytes and epithelial cells of lung tissue express VEGF and VEGF receptors. ${ }^{14,15}$ Exogenous administration of VEGF in respiratory distress syndrome improves aeration and surfactant protein production. ${ }^{16}$ In the lung, VEGF mRNA and protein are localized to distal airway epithelial cells and the basement membrane subjacent to the airway epithelial cells. ${ }^{17}$

VEGF is present in alveolar type II cells in the developing mouse lung and its expression peaks during the canalicular stage, when most of the vessel growth occurs in the lung. This suggest the essential role of VEGF in vasculogenesis and alveolar development. ${ }^{18}$ previously we have studied the effect of retinoic alone in improving oxygenation of compensatory lung following unilateral pneumonectomy. ${ }^{19}$

The purpose of this study is to investigate whether the combined effect of retinoic acid and VEGF on compensatory lung growth with respect to weight, volume of the residual lung and increase in the functional capacity of lung in terms of oxygenation in rats following unilateral pneumonectomy. Addition of VEGF to RA might be a new treatment strategy to improve the oxygenation and quality of life in patients that undergone complete or partial pneumonectomy, especially in those with limited respiratory reserve.

\section{METHODS}

\begin{abstract}
Animals
Male Wistar albino rats weighing 200-250 gm were used in the study. They were housed and maintained under standard condition in the central animal house. The rats were kept in clean, clear polypropylene cages in groups of three in each cage maintained at 12 hour light and dark cycle. They were maintained under standard environmental conditions and fed with standard pellet diet (laboratory animal feeds) and water ad libitum.
\end{abstract}

\section{Experimental design}

The study was carried out after obtaining approval by the institutional animal's ethics committee (1463/PO/a/11/CPCSEA). Forty rats were used in this study. They were divided into four groups of ten animals each. The vehicle/drug was administered for a period 10 days from the day of surgery. Drug/vehicle was administered intraperitoneally (i.p) under aseptic conditions.

\section{The treatment schedule was as follows}

Group I: Sham group, animals underwent sham thoracotomy on the left side with no lung resection and no drug treatment.

Group II: Control group, animals underwent left pneumonectomy and no drug treatment.

Group III: Retinoic acid group, animals underwent left pneumonectomy with the administration of exogenous retinoic acid $(0.5 \mu \mathrm{g} / \mathrm{g} /$ day $)$ intraperitoneally. ${ }^{20}$

Group III: Retinoic acid with VEGF group, animals underwent left pneumonectomy with the administration of exogenous retinoic acid $(0.5 \mu \mathrm{g} / \mathrm{g} /$ day $)$ intraperitoneally 20 and VEGF $(5 \mu \mathrm{g} /$ day $)$ intraperitoneally. ${ }^{21}$

\section{Operative model}

Initial body weights of the rats were measured. The animals were premedicated approximately $30 \mathrm{~min}$ before surgery with an intramuscular atropine sulphate injection $0.4 \mathrm{mg} / 100 \mathrm{~g}$ body weight to lessen the bronchial secretions. Animals were anaesthetized with ketamine $(100 \mathrm{mg} / \mathrm{kg})$ intraperitoneally. ${ }^{19,22,23}$

The left side of the chest was shaved and painted with povidone and alcohol. A skin incision was made approximately an inch long along the anterior midaxillary line. The skin was separated from the muscular layer by blunt dissection. The muscular layer was incised by cutting the fifth intercostals space and the thoracic cavity opened. The hilum of the left lung was ligated with 3.0 catgut suture and the left lung is freed from pulmonary ligament and removed under aseptic condition. 
The right lung was gently inflated with air. The ribs were approximated and thoracic cavity was closed with 3.0 catgut sutures. The muscular layer and skin was closed in 2 layers with interrupted sutures. The surgery-induced pneumothorax will be reduced by inserting a hypodermic needle through the chest wall and withdrawing air until negative pressure is achieved. The surgical procedure was done without tracheal intubation. ${ }^{19,23}$ Amoxicillinclavulanic acid suspension was given orally to minimize the chances of post-operative infection. Tramadol was given intramuscularly to relieve postoperative pain. Sham operations was similarly performed on sham group with a simple left thoracotomy but left lung will be neither ligated nor removed.

\section{Arterial blood gas analysis}

On $11^{\text {th }}$ post-operative day the animals were anaesthetized with ketamine and blood sample for arterial blood gas analysis was collected from abdominal aorta. Arterial blood gas samples were collected in heparinized syringes and analyzed within $30 \mathrm{~min}$ after withdrawal, at $37^{\circ} \mathrm{C}$ without temperature correction.

\section{Estimation of DNA content}

On 11th post-operative day the lung tissue was removed and preserved in freshly prepared phosphate buffer solution. The tissue was homogenized and the DNA samples were stored at $-20^{\circ} \mathrm{C}$. $1 \mathrm{ml}$ of Tris-EDTA (TE) buffer was calibrated using spectrophotometer at $260 \mathrm{~nm}$ and $280 \mathrm{~nm}$. $10 \mu \mathrm{l}$ of DNA sample was added to $900 \mu \mathrm{l}$ of TE buffer and mixed well. Blank TE buffer was used in the other cuvette of the spectrophotometer and the OD260 and OD280 values were read on spectrophotometer. The ratio of OD260/OD280 was calculated and the amount of DNA was quantified.

\section{Estimation of Protein content}

Protein concentration of the crude tissue extracts was determined by the method of Lowry et al. ${ }^{24}$ Bovine serum albumin (BSA) dissolved in $0.1 \mathrm{M} \mathrm{NaOH}$ was used as standard stock solution. The stock solution was divides into aliquots and stored at $-20^{\circ} \mathrm{C}$ until required for an assay. Lung samples were diluted to 1:10 with distilled water. A tube with $1 \mathrm{ml}$ of distilled water serves as a blank. $5 \mathrm{ml}$ of freshly prepared Lowry's solution $(2 \%$ sodium carbonate solution in $0.1 \mathrm{M} \mathrm{NaOH}, 1 \%$ copper sulphate solution, $2 \%$ sodium tartrate solution and all mixed in 100:1:1 ratio) was added, vortexed and allowed to be at room temperature for 15 minutes. Then $0.5 \mathrm{ml}$ of Folin's reagent (2N Folin-ciocalteau reagent diluted with distilled water and $1 \mathrm{M} \mathrm{NaOH}$ to final $\mathrm{pH}$ of 1.8) was added, mixed well and incubate at room temperature in the dark for 30 minutes. The absorbance was read at 660 $\mathrm{nm}$ in a spectrophotometer. Absorbance readings were all within the linear range of the standard curve. By approximating the absorbance on the standard curve, protein contents per sample was calculated.

\section{Statistical analysis}

All values are expressed as mean \pm SEM. Data was analyzed using one-way ANOVA. Post-hoc comparisons were performed by applying Bonferroni test. $\mathrm{P}<0.05$ was considered statistically significant. All statistical analyses were carried out by using SPSS for Windows (SPSS 17.0).

\section{RESULTS}

The rats were sacrificed; their thoracic cavity and the right lung tissue were examined macroscopically before and after removing the contralateral lung. It was observed that the contralateral right lung tissue has expanded largely into the left thoracic cavity much more in drug treated groups and partially in untreated group. The lung tissues were normal and occupied the left thorax almost completely in drug treated groups.

Weight of the compensatory lung after left pneumonectomy was significantly increased in rats treated with retinoic acid $(1.39 \pm 0.16)$ and retinoic acid with VEGF $(1.45 \pm 0.15)$ as compared to control $(1.09 \pm 0.22)$. The volume of the compensatory lung was also significantly increased in rats treated with retinoic acid (11.12 \pm 0.11$)$ and retinoic acid with VEGF $(11.64 \pm 0.15)$ as compared to control $(9.39 \pm 0.11)$. Similarly protein and DNA content was also significantly

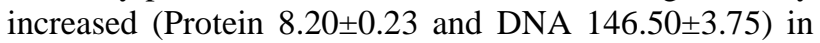
rats treated with retinoic acid and (Protein 9.48 \pm 0.21 and DNA 162.11 \pm 3.11 ) in rats treated with retinoic acid with VEGF as compared to control (Protein 5.09 \pm 0.24 and DNA $102.37 \pm 1.78)$. It was also observed that rats treated with retinoic acid in combination with VEGF showed a significant increase in volume, protein content in compensatory lung compared to rats treated with retinoic acid alone. The significance of the result indicates the compensatory lung growth was accelerated in rats treated with retinoic acid and retinoic acid in combination with VEGF as compared to untreated control group of rats. (Table 1)

\section{Arterial blood gas analysis}

Arterial blood gas (ABG) analysis of samples collected on $11^{\text {th }}$ day, there was a significant increase in partial pressure of oxygen in rats treated with retinoic acid $\left(\mathrm{PaO}_{2}=30.80 \pm 0.90\right)$ and retinoic acid in combination with VEGF $\left(\mathrm{PaO}_{2}=44.50 \pm 1.26\right)$ compared to control $\left(\mathrm{PaO}_{2}=25.80 \pm 0.80\right)$. There was significant improvement in partial pressure of carbondioxide $\left(\mathrm{PaCO}_{2}\right)$ and saturation of oxygen percentage $\left(\mathrm{SO}_{2} \%\right)$ in rats treated with retinoic acid in combination with VEGF $\left(\mathrm{PaCO}_{2}=41.30 \pm 0.60\right.$ and $\left.\mathrm{SO}_{2} \%=76.78 \pm 0.80\right)$ than in rats treated with retinoic acid alone $\left(\mathrm{PaCO}_{2}=47.26 \pm 0.57\right.$ and $\left.\mathrm{SO}_{2} \%=42.53 \pm 1.48\right)$ and control $\left(\mathrm{PaCO}_{2}=48.20 \pm 0.47\right.$ and $\left.\mathrm{SO}_{2} \%=38.70 \pm 1.45\right)$. The result shows that there is better improvement in arterial blood gases in rats treated with 
combination of retinoic acid and VEGF than in rats treated with retinoic acid alone (Table 2)

Table 1: Effect of retinoic acid on lung weight, lung volume, protein and DNA content.

\begin{tabular}{|c|c|c|c|c|}
\hline Group & Right lung wt (gm) & Right lung volume (ml) & $\begin{array}{l}\text { Protein conc. in } \\
\text { right lung }(\mu \mathrm{g})\end{array}$ & DNA conc. in right lung $(\mu \mathrm{g})$ \\
\hline Sham control & $0.79 \pm 0.01$ & $6.11 \pm 0.13$ & $4.23 \pm 0.08$ & $72.11 \pm 1.39$ \\
\hline Control & $1.09 \pm 0.22^{\mathrm{a}}$ & $9.39 \pm 0.11^{\mathrm{a}}$ & $5.09 \pm 0.24^{\mathrm{a}}$ & $102.37 \pm 1.78^{\mathrm{a}}$ \\
\hline Retinoic acid & $1.39 \pm 0.16^{\mathrm{a}, \mathrm{b}}$ & $11.12 \pm 0.11^{\mathrm{a}, \mathrm{b}}$ & $8.20 \pm 0.23^{\mathrm{a}, \mathrm{b}}$ & $146.50 \pm 3.75^{\mathrm{a}, \mathrm{b}}$ \\
\hline $\begin{array}{l}\text { Retinoic acid } \\
\text { with VEGF }\end{array}$ & $1.45 \pm 0.15^{\mathrm{a}, \mathrm{b}}$ & $11.64 \pm 0.15^{\mathrm{a}, \mathrm{b}}$ & $9.48 \pm 0.21^{\mathrm{a}, \mathrm{b}, \mathrm{c}}$ & $162.11 \pm 3.11^{\mathrm{a}, \mathrm{b}, \mathrm{c}}$ \\
\hline
\end{tabular}

Values are expressed as mean $\pm \mathrm{SEM}, \mathrm{n}=10$ in each group. (ANOVA followed by Bonferroni's test) ${ }^{\mathrm{a}} \mathrm{P}<0.05$ as compared to sham control. ${ }^{\mathrm{b}} \mathrm{P}<0.05$ as compared to control, ${ }^{\mathrm{c}} \mathrm{P}<0.05$ as compared to retinoic acid (ANOVA followed by Bonferroni's test).

Table 2: Effect of retinoic acid on arterial blood gases.

\begin{tabular}{|llll|}
\hline Group & $\mathrm{PaO}_{2}(\mathbf{m m H g})$ & $\mathbf{P a C O}_{2}(\mathbf{m m H g})$ & $\mathbf{S O}_{2} \%$ \\
\hline Sham control & $48.00 \pm 1.34$ & $43.12 \pm 1.74$ & $81.18 \pm 1.17$ \\
\hline Control & $25.80 \pm 0.87$ & $48.20 \pm 0.47$ & $38.70 \pm 1.45$ \\
\hline Retinoic acid & $30.80 \pm 0.90^{\mathrm{a}}$ & $47.26 \pm 0.57$ & $42.53 \pm 1.48$ \\
\hline Retinoic acid with VEGF & $44.50 \pm 1.26^{\mathrm{a}, \mathrm{b}}$ & $41.30 \pm 0.60^{\mathrm{a}, \mathrm{b}}$ & $76.78 \pm 0.80^{\mathrm{a}, \mathrm{b}}$ \\
\hline
\end{tabular}

Values are expressed as mean \pm SEM, $\mathrm{n}=10$ in each group. (ANOVA followed by Bonferroni's test) ${ }^{\mathrm{a}} \mathrm{P}<0.05$ as compared to control. ${ }^{\mathrm{b}}$

$\mathrm{P}<0.05$ as compared to retinoic acid.

\section{DISCUSSION}

Lung volume reduction surgery (LVRS) is one of the surgical procedures done for severe emphysema and chronic obstructive pulmonary disease, where either a lobectomy of unilateral pneumonectomy is performed to remove the damaged lung, to allow the remaining lung tissue to expand. LVRS can impair lung function because of removal of a large part of lung tissue. The lung contains putative resident progenitor stem cells, the type II pneumocytes. These are large, relatively undifferentiated cells that are often seen proliferating and are known to possess the RA signal transduction components. ${ }^{25}$ Retinoic acid being a signalling molecule that plays a major role during embryonic morphogenesis, controls fetal lung growth. RA can induce the regeneration of lung alveoli in the experimentally damaged adult rat lung. ${ }^{26}$ Retinoic acid is essential for the alveolar repair process in adult rats. ${ }^{27}$

In the pulmonary system, angiogenesis is of particular importance because the blood-air interface is the sole source of oxygen delivery to the body. In the pulmonary system, angiogenesis is of particular importance because the blood-air interface is the sole source of oxygen delivery to the body. Vascular endothelial growth factor (VEGF) is the most potent directly acting regulator of angiogenesis and a trophic factor that is required for the survival of endothelial cells, inducing endothelial cell proliferation. ${ }^{28-30}$ VEGF has been shown to be deposited in the subepithelial matrix at the leading edges of branching airways where it stimulates angiogenesis. ${ }^{31}$ It has also been demonstrated that during pulmonary distention, a stimulus for alveolarization (capillary and alveolar growth) upregulated VEGF mRNA and led to the hypothesis that angiogenesis is a rate-limiting factor in this process. ${ }^{32}$ VEGF driven angiogenesis is critical for normal lung alveolar development. VEGF treatment induces formation of new lung blood vessels, and this treatment improves lung development in an experimental model of chronic lung disease. ${ }^{33}$

In the present study, macroscopic examination shows that the compensatory lung had enlarged proportionately and occupied the thorax of the pneumonectomized side. Retinoic acid when given along with VEGF has increased the weight, volume, protein concentration and DNA concentration of compensatory lung beyond that of the untreated group of rats. Increase in DNA concentration of the compensatory lung suggestive of proliferation of type II pneumocytes present in lung. Our data suggest that, retinoic acid and VEGF is essential to accelerate the compensatory growth of remaining lung tissue following complete or partial pneumonectomy. Retinoic acid increased the partial pressure of oxygen as compared to control, but it does not improve the oxygen saturation percentage significantly. Addition of VEGF to retinoic acid has significantly improved oxygen saturation in ABG analysis. This suggested that, VEGF induces formation of new lung blood vessels during compensatory lung growth which is essential for improved oxygenation of the blood.

\section{ACKNOWLEDGEMENT}

The author would like to express his gratitude towards department of Pharmacology, AMCH, Salem for their invaluable technical assistance and special thanks to his 
family members for their kind co-operation and encouragement in completion of this study.

Funding: No funding sources

Conflict of interest: None declared

Ethical approval: The study was approved by the Institutional Ethics Committee

\section{REFERENCES}

1. Department of Health and Human Services. Lung volume reduction surgery and medicare coverage policy: implications for recently published evidence. In: Health care financing administration report to congress. Washington: Department of Health and Human Services; 1998.

2. Cooper JD, Patterson GA, Sundaresan RS, Trulock EP, Yusen RD, Pohl MS, et al. Results of 150 consecutive bilateral lung volume reduction procedures in patients with severe emphysema. J Thorac Cardiovasc Surg. 1996;112:1319-30.

3. Cagle PT, Langston C, Goodman JC, Thurlbeck WM. Autoradiographic assessment of the sequence of cellular proliferation in postpneumonectomy lung growth. Am J Respir Cell Mol Biol. 1990;3:153-8.

4. Masuyama H, Hiramatsu Y, Kudo T. Effect of retinoids on fetal lung development in the rat. Biol Neonate. 1995;67:264-73.

5. Massaro GD, Massaro D. Postnatal treatment with retinoic acid increases the number of pulmonary alveoli in rats. Am J Physiol Lung Cell Mol Physiol. 1996;270:305-10.

6. Nabeyrat E, Besnard V, Corroyer S, Cazals V, and Clement A. Retinoic acid-induced proliferation of lung alveolar epithelial cells: relation with the IGF system. Am J Physiol Lung Cell Mol Physiol. 1998;275:71-9.

7. Wolbach SB, Howe PR. Tissue changes following deprivation of fat-soluble A vitamin. J Exp Med. 1925;42:753-77.

8. Wolbach SB, Howe PR. Epithelial repair in recovery from vitamin A deficiency. J Exp Med. 1993;57:511-26.

9. Fraslon C, Bourbon JR. Retinoids control surfactant phospholipid biosynthesis in fetal rat lung. Am J Physiol Lung Cell Mol Physiol. 1994;266:705-12.

10. George TN, Miakotina OL, Goss KL, Snyder JM. Mechanism of all-trans retinoic acid and glucocorticoid regulation of surfactant protein mRNA. Am J Physiol Lung Cell Mol Physiol. 1998;274:560-6.

11. Malpel S, Mendelsohn C, Cardoso WV. Regulation of retinoic acid signaling during lung morphogenesis. Development. 2000;127:3057-67.

12. Antipatis C, Grant G, Ashworth CJ. Moderate maternal vitamin A deficiency affects perinatal organ growth and development in rats. $\mathrm{Br} \mathrm{J}$ Nutr. 2000;84:125-32.

13. Jakkula M, Le Cras TD, Gebb S, Hirth KP, Tuder $\mathrm{RM}$, Voelkel NF, et al. Inhibition of angiogenesis decreases alveolarization in the developing rat lung. Am J Physiol Lung Cell Mol Physiol. 2000;279:600-7.

14. Kaner RJ, Crystal RG. Compartmentalization of vascular endothelial growth factor to the epithelial surface of the human lung. Mol Med. 2001;7:240-6.

15. Klekamp JG, Jarzecka K, Perkett EA. Exposure to hyperoxia decreases the expression of vascular endothelial growth factor and its receptors in adult rat lungs. Am J Pathol. 1999;154:823-31.

16. Compernolle V, Brusselmans K, Acker T, Hoet P, Tjwa M, Beck H, et al. Loss of HIF-2alpha and inhibition of VEGF impair fetal lung maturation, whereas treatment with VEGF prevents fatal respiratory distress in premature mice. Nat Med. 2002;8:702-10.

17. Healy AM, Morgenthau L, Zhu X, Farber HW, Cardoso WV. VEGF is deposited in the sub epithelial matrix at the leading edge of branching airways and stimulates neovascularization in the murine embryonic lung. Dev Dyn. 2000;219:341-52.

18. Ng YS, Rohan R, Sunday ME, Demello DE, D'Amore PA. Differential expression of VEGF isoforms in mouse during development and in the adult. Dev Dyn. 2001;220:112-21.

19. Saravanan R, Rajaram S. Effect of retinoic acid on arterial blood gases, protein and DNA content in rat lung following unilateral pneumonectomy. Int $\mathbf{J}$ Pharmacology Res. 2016;6(1):63-7.

20. Aditya K. Kaza et al. Retinoic acid enhances lung growth after pneumonectomy. Ann Thrac Surg. 2001;71:1645-50.

21. Chen CM, Wang LF. High-dose vascular endothelial growth factor increases surfactant protein gene expressions in preterm rat lung. Early Human Development. 2007;83:581-4.

22. Karapolat S, Sanli A, Onen A, Acikel U, Sivrikoz O. Effects of retinoic acid on compensatory lung growth. J cardio surg. 2008;3(1):1-9.

23. Rombola CA, Tagliaferri EM, Boue AA, GarciaMDJ, Picazo MG, Garcia DC. Pneumonectomy in isoflurane-anesthetized rats without tracheal intubation: an experimental model. The Thoracic and Cardiovascular surgeon. 2014;62(2):169-73.

24. Oliver H, Lowry, Nira J, Rosebrough A, Farr L, Rose JR. Protein measurement with the folin phenol reagent. J Biol Chem. 1951;265-75.

25. Naltner A, Ghaffari M, Whitsett JA, Yan C. Retinoic acid stimulation of the human surfactant protein $B$ promoter is thyroid transcription factor 1 sitedependent. J Biol Chem. 2000;275:56-2.

26. Massaro GDC, Massaro D. Retinoic acid treatment abrogates elastase-induced pulmonary emphysema in rats. Nature Med. 1997;3:675-7.

27. Baybutt RC, Hu L, Molteni A. Vitamin A deficiency injures the lung and liver parenchyma and impairs function of rat type II pneumocytes. J Nutr. 2000;130:1159-65.

28. Leung DW, Cachianes G, Kuang WJ, Goeddel DV, Ferrara N. Vascular endothelial growth factor is a 
secreted angiogenic mitogen. Science. 1989;246:1306-9.

29. Chetta A, Zanini A, Foresis A, Díppolito R, Tipa A, Castagnaro A, et al. Vascular endothelial growth factor up-regulation and bronchial wall remodeling in asthma. Clin Exp Allergy. 2005;35:1437-42.

30. Neufeld G, Cohen T, Gengrinovitch S, Poltorak Z. Vascular endothelial growth factor (VEGF) and its receptors. Federation of American Societies for Experimental Biology. 1999;13:9-22.

31. Healy AM, Morgenthau L, Zhu X, Farber HW, Cardoso WV. VEGF is deposited in the subepithelial matrix at the leading edge of branching airways and stimulates neovascularization in the murine embryonic lung. Dev Dyn. 2000;219:341-52.

32. Muratore CS, Nguyen HT, Ziegler MM, Wilson JM. Stretch-induced up-regulation of VEGF gene expression in murine pulmonary culture: a role for angiogenesis in lung development. J Pediatr Surg. 2000;35:906-12.

33. Thébaud B, Ladha F, Michelakis D, Sawicka M, Thurston G, Eaton F, et al. Vascular endothelial growth factor gene therapy increases survival, promotes lung angiogenesis, and prevents alveolar damage in hyperoxia-induced lung injury. evidence that angiogenesis participates in alveolarization. Circulation. 2005;112:2477-86.

Cite this article as: Saravanan $\mathrm{R}$, Rajaram S. Combined effect of retinoic acid and vascular endothelial growth factor on compensatory lung growth following unilateral pneumonectomy in rats. Int J Basic Clin Pharmacol 2016;5:1075-80. 